\title{
GAMBARAN KEBIASAAN MEROKOK ANGGOTA KELUARGA DENGAN KEJADIAN INFEKSI SALURAN PERNAFASAN AKUT (ISPA) PADA BALITA DI WILAYAH KERJA PUSKESMAS PONRE KECAMATAN GANTARANG KABUPATEN BULUKUMBA
}

\author{
Haerani $^{1 *}$, Sri Ningsih ${ }^{1}$, Siti Usmia $^{1}$, Isnayanti ${ }^{1}$, Sumarni $^{1}$, Nita Ariani Nur ${ }^{1}$, A. Maya Rupa $A^{1}$, \\ Nurul Hidayah Bohari ${ }^{1}$, Mudyawati Kamaruddin ${ }^{1}$ \\ ${ }^{1}$ Program Studi Kebidanan, Akademi Kebidanan Tahirah Al Baeti, Bulukumba, Sulawesi Selatan \\ *Corresponding author: Telp: +6285242473342, email: haeranirani987@gmail.com
}

\begin{abstract}
ABSTRAK
Infeksi Saluran Pernafasan Akut atau dikenal sebagai ISPA merupakan masalah kesehatan masyarakat Indonesia terutama pada balita.. Salah satu faktor dari insidensi infeksi saluran pernafasan akut (ISPA) pada balita adalah adanya anggota keluarga yang merokok. Jenis penelitian ini adalah penelitian deskriptif kuantitatif, dengan jumlah sample sebanyak 50responden.Tehnik pengumpulan data menggunakan instrument kuesioner, dan teknik analisis data menggunakan analisis deskriptif kuantitatif. Penelitian ini menunjukan bahwa sebagian besar 32 balita (64\%) anggota keluarga balita penderita ISPA adalah perokok. Anggota keluarga balita penderia ISPA berada dalam kategori perokok sedang sebanyak 24 balita (48\%) dan 15 balita (28\%). Dari 50 balita yang menderita ISPA memiliki anggota keluarga yang tinggal bersama dengan kebiasaan merokok sebanyak 29 balita $(58 \%)$ anggota keluarga yang memiliki kebiasaan merokok tidak memperhatikan lingkungan sebanyak 21 balita (42\%). Hasil ini juga menunjukkan bahwa dari 50 anggota keluarga dengan kebiasaan merokok ringan (1-10 btg/hari) sebanyak 11 balita (22\%), 24 balita yang memiliki jumlah anggota keluarga dengan merokok sedang (1120 btg/hari) sebanyak 24 balita (48\%) dan 15 balita (30\%) yang memiliki jumlah anggota keluarga dengan kebiasaan merokok berat (20 btg/hari).Simpulan yang dapat ditarik adalah penelitian ini menunjukkan bahwa balita yang menderita ISPA pada umumnya disebabkan karena adanya anggota keluarga yang memiliki kebiasaan merokok di rumah dan tanpa memperhatikan lingkungan sekitarnya. Diharapkan bagi peneliti selanjutnya dapat dijadikan tambahan referensi yang berhubungan dengan kejadian ISPA pada balita.
\end{abstract}

Kata kunci : merokok, penderita ISPA.

\section{ABSTRACT}

Acute Respiratory Infection (ARI) in Indonesia is a major health problem in Indonesia especially for toddlers. One of the causative factors of acute respiratory infection on toddler under five is the family smoking habits. This research employs the descriptive quantitative method. Samples were determined using technique of sampling so-called purposive, and the instrument used in this research was questionnaire. The results show that there are 45 respondents (90\%) have smoking habits who living with toddlers suffering with Acute Respiratory Infection (ARI), and the rest 5 respondents (10\%) have not smoking habits. There are 30 respondents (60\%) have smoking habits by not paying attention to the environment with toddlers around them, while 20 respondents (40\%) paying attention to the environment. 18 toddlers (36\%) have only one family member with smoking habit, and 32 toddlers have more than one family member with smoking habit. The result also reveals that there are 11 toddlers (22\%) have family members categorized as mild smoker ( 1 - 10 cigarettes/day), moderate smoker (11 - 20 cigarettes/day) 24 toddles (48\%), and severe smoker (20 cigarettes /day) 15 toddles (30\%). Conclusion: Base in the results above, it can be concluded that the large numbers of toddlers suffering with Acute Respiratory Infection (ARI) are caused by family members who have smoking habit without paying attention to environment with toddlers around them.

Keywords: Smoking, ARI, Toddlers. 


\section{PENDAHULUAN}

Masalah kesehatan anak merupakan salah satu masalah utama dalam bidang kesehatan yang saat ini terjadi di negara sedang berkembang seperti indonesia. Derajat kesehatan anak mencerminkan derajat kesehatan bangsa, sebab anak sebaga generasi penerus bangsa memiliki kemampuan yang dapat dikembangkan dalam meneruskan pembangunan bangsa.berdasarkan alasan tersebut maka masalah kesehatan anak diprioritaskan dalam perencanaan atau penataan pembangunan bangsa ${ }^{1}$.

ISPA merupakan kepanjangan dari infeksi saluran pernafasan akut.Infeksi saluran pernafasan akut (ISPA) merupakan infeksi yang menyerang saluran pernafasan bagian atas dan infeksi saluran pernafasan bagian bawah.infeksi saluran pernafasan akut (ISPA) masih menjadi permasalah kesehatan dunia, khususnya yang terjadi pada balita $^{2}$, angka kematian pada anak usia dibawah lima tahun (balita) pada tahun 2013 sebesar 6,3 juta atau sekitar 17.000 balita meninggal dunia setiap hari. Penyebab kematian balita yaitu ISPA Akut (13\%), diare (9\%), malaria (7\%), dan anomalia konginital dan penyakit tidak menular $(7 \%)$.

Menurut Depkes RI (2014) ${ }^{3}$, di Indonesia pada tahun 2014, angka kematian akibat ISPA pada balita sebesar 8 per 10.000 balita, lebih rendah dibandingkan dengan tahun 2013, yang sebesar 119 per 10.000 balita. Pada kelompok bayi angka kematian lebih tinggi yaitu sebesar 11 per 10.000 bayi dibandingkan pada kelompok umur 14 tahun yang sebesar 6 per 10.000 balita.

Berdasarkan data profil kesehatan propinsi sulawesi selatan terdapat $(18,58 \%)$ penderita pneumonia pada tahun 2016 dan pada tahun 2017, terdapat $(19,27 \%)$ penderita pneumonia, dari data tersebut mengalami meningkatan infeksi saluran pernafasan akut (ISPA) pada balita (Profil Kesehatan Propinsi Sulawesi Selatan).

Menurut Umami (2014) $)^{4}$, bahwa ISPA terjadi apabila kekebalan tubuh menurun. Beberapa upaya dapat dilakukan untuk menurunkan resiko penyakit ISPA, antara lain dengan menghilangkan kebiasaan merokok dirumah. Sehingga dia menyimpulkan bahwa ada hubungan antara antar kebiasaan merokok dengan kejadian ISPA pada anak.

Pendataan yang dilakukan oleh Dinas Kesehatan Kabupaten Bulukumba pada tahun Januari 2017 Desember 2018, jumlah ISPA pada balita sebanyak 738 insiden (Profil kesehatan Kab.Bulukumba,2017) dan jumlah ISPA pada balita per September 2018 sebanyak 324 insiden
(Profil kesehatan Kab.Bulukumba,2018). Data sekunder yang diperoleh dari Puskesmas Ponre Kec. Gantarang, Kab. Bulukumba tahun 2017, ditemukan kejadian ISPA pada balita sebanyak 105 insiden dan pada pendataan tahun 2018 menurut pelaporan hingga bulan Oktober ditemukan ISPA sebanyak 88 insiden (Wilayah Kerja Puskesma Ponre Kec. Gantarang, Kab. Bulukumba).

\section{METODOLOGI}

\section{Jenis dan Rencana Penelitian}

Penelitian ini merupakan penelitian kuantitatif dengan menggunakan desain deskriptif serta pendekatan restrospektif.Penelitian ini ingin menetahui gambaran kebiasaan merokok anggota keluarga pada balita yang menderita infeksi saluran pernafasan akut (ISPA) di Wilayah Kerja Puskesmas Ponre.

\section{Waktu dan Tempat Penelitian}

1. Waktu Penelitian

Waktu penelitian adalah jangka waktu yang dibutuhkan penulis untuk memperoleh data studi kasus yang dilaksanakan ${ }^{5}$. Penelitian ini dilaksanakan pada tanggal 27 november 2018 - 8 juni 2019.

2. Tempat Penelitian

Tempat penelitian adalah tempat yang digunakan untuk pengambilan data selama kasus berlangsung ${ }^{5}$, Penelitian akandilakukan di wilayah Puskesmas Ponre, Kabupaten Bulukumba, Sulawesi Selatan.

\section{Populasi, Sampe dan Teknik Pengambilan Sampel}

1. Populasi

Populasi adalah keseluruhan obyek penelitian yang memiliki karakteristik tertentu yang ditetapkan oleh peneliti untuk dipelajari kemudian ditarik kesimpulannya. Populasi dalam penelitian ini adalah semua balita yang menderita infeksi saluran pernafasan akutr ( ISPA) Di Wilayah Kerja Puskesmas Ponre Tahun 2017 Sebanyak 105 orang pada penelitian ini di kelompokan Pada umur balita yang berusia di bawah $\geq 1$ tahun terdapat 20 balita dan pada umur 2-4 tahun terdapat 30 balita.

2. Sampel

Sampel adalah sebagian yang diambil dari keseluruhan objek yang diteliti dan dianggap mewakili seluruh populasi (Sastroasmoro 2014). Sampel dalam penelitian ini adalah balita yang menderita infeksi saluran 
pernafasan akut (ISPA) di wilayah kerja Puskesmas Ponre sebanyak 50 orang yang ditentukan melalui rumus Slovin:

$$
\mathrm{n}=\frac{\mathrm{N}}{1+\mathrm{N} \mathrm{a}^{2}}
$$

Keterangan :

$\mathrm{n}$ : ukuran sampel yang dibutuhkan

$\mathrm{N}$ : Jumlah populasi

a : Margin error yang diperkenakan atau

tarif dignifikasi dan $0,10(10 \%)$.

3. Teknik Pengambilan Sampel

Pengambilan sampel dalam penelitian ini adalah Porposive sampling.Karena populasi yang digunakan relatif besar.Porposive sampling adalah pengambilan sampel yang berdasarkan atas suatu pertimbangan tertentu seperti sifat-sifat populasi ataupun ciri-ciri yang sudah diketahui sebelumnya ${ }^{5}$.

Berikut ini kriteria inklusi sampel keadaan balita

a. Bayi yang menderita ISPA di kelompokkan pada umur $\geq 1$ terdapat 20 balita dan pada kelompok umur balita 1- 4 terdapat 30 balita.

b. Datang ke pelayanan kesehatan Puskesmas Ponre

c. Bersedia menjadi responder dan bersedia diwawancara dalam penelitian

d. Berdomisili di wilayah kerja Puskesmas Ponre

e. Keluarga yang memiliki anggota keluarga yang merokok

Berikut ini kreteria eklusi sampel penelitian :

a. Bayi yang tidak menderita ISPA

b. Berdomisili di wilayah kerja Puskesmas Ponre

c. Bayi yang tidak memiliki anggota keluarga yang merokok.

\section{Ruang Lingkup Penelitian}

Ruang lingkup penelitian ini mencakup tentang kebiasaan merokok anggota keluarga dengan kejadian Infeksi Saluran Pernafasan Akut (ISPA) Pada balita Di wilayah kerja Puskesmas Ponre.

\section{Metode Pengumpulan Data}

Data sekunder di peroleh dari data yang dimiliki Dinas Kesehatan Kabupaten bulukumba dandata sekunder Puskesmas Ponre Kecamatan Gantarang Kabupaten Bulukumba.
Data primer di peroleh dari hasil interview langsung dengan mendatangi orang tua balita untuk mendapatkan informasi lebih rinci dan melalui wawancara dengan menggunakan Kuesioner.

\section{Analisa Data}

Analisis univariat merupakan analisis yang dilakukan pada setiap variabel penelitian dan bertujuan untuk mengetahui deskripsi karakterestik setiap variabel dalam penelitian ${ }^{5}$. Analisis univariat dalam penelitian ini bertujuan untuk memeberikan gambaran distribusi karakteristik jenis kelami, usia, pendidikan ibu serta gambaran kebiasaan merokok anggota keluarga berdasarkan lokasi merokok, jumlah anggota keluarga yang merokok dan banyaknya rokok yang dihirup setiap hari.

Dalam analisa data dideskripsikan angka atau nilai jumlah variabel dengan ukuran presentase dengan menggunakan rumus frekuensi presentase (Sugiyono, 2013).

$$
\mathrm{P}=\frac{F}{N} \times 100 \%
$$

Keterangan:

$\mathrm{F}$ : Jumlah frekuensi

$\mathrm{N}$ : Jumlah responden yang diseleksi

$\mathrm{P}$ :Angka presentase

\section{HASIL DAN PEMBAHASAN}

HASIL

Berikut ini adalah hasil penelitian mengenai Gambaran Kebiasaan Merokok Anggota Keluarga Dengan Kejadian Infeksi Saluran Pernafasan Akut (ISPA) Pada Balita Di Wilayah Kerja Puskesmas Ponreyang dilaksanakan pada tanggal 10 Mei sampai dengan 10 juni 2019, Dalam penelitian ini digunakan tekhnik pengumpulan data dengan cara membagikan format lembar kuesioner kepada responden dengan pertanyaan sebanyak 9 nomor.Tekhnik pengambilan sampel dengan menggunakan metode Porposive sampling. Berikut akan di jelaskan hasil penelitian tentang Gambaran Kebiasaan Merokok Anggota Keluarga Dengan Kejadian Infeksi Saluran Pernafasan Akut (ISPA) Pada Balita Di Wilayah Kerja Puskesmas Ponre. 
1. Karakteristis Responden Wilayah Kerja Puskesmas Ponre

Tabel 1 Distribusi Frekuensi Responden Berdasarkan Pekerjaan Wilayah Kerja Puskesmas Ponre

\begin{tabular}{lcc}
\hline Pekerjaan & Frekuensi & $\%$ \\
\hline Karyawan & 2 & 4,0 \\
\hline Petani & 31 & 62,0 \\
\hline PNS & 2 & 4,0 \\
\hline Wiraswasta & 15 & 30,0 \\
\hline Jumlah & 50 & 100 \\
\hline
\end{tabular}

Sumber : Data Primer (2019)

Berdasarkan tabel 4.1 menunjukan bahwa dari 50 responden yang diteli terdapat 2 responden $(4,0 \%)$ berstatus sebagai Karyawan, 31 responden $(62,0 \%)$ berstatus sebagai Petani, 2 responden $(4,0 \%)$ berstatus sebagai PNS, dan 15 responden $(30,0 \%)$ berstatus sebagai Wiraswasta.

2. Karekteristik Responden Berdasarkan Pendidikan Wilayah Kerja Puskesmas Ponre

Tabel 2 Distribusi Frekuensi Responden Berdasarkan Pendidikan

\begin{tabular}{lcc}
\hline Pendidikan & Frekuensi & $\%$ \\
\hline D3 & 1 & 2,0 \\
\hline S1 & 3 & 6,0 \\
\hline SD & 11 & 22,0 \\
\hline SMA & 6 & 12,0 \\
\hline SMP & 11 & 22,0 \\
\hline Tidak & 18 & 36,0 \\
Sekolah (TS) & & \\
\hline Jumlah & 50 & 100 \\
\hline \multicolumn{2}{l}{ Sumber : Data Primer (2019) }
\end{tabular}

Tabel 2 menunjukan bahwa dari 50 responden yang diteliti terdapat 1 responden $(2,0 \%)$ Diploma, 3 responden $(6,0 \%)$ berpendidikan Sarjana (S1), 11 responden $(22,0 \%)$ berpendidikan Sekolah Dasar, 6 responden $(12,0 \%)$ berpendidkan Sekolah Menengah Atas (SMA), 11 responden (22,0\%) berpendidikan Sekolah Menengah Pertama (SMP), dan 18 responden $(36,0)$ tidak sekolah.

3. Gambaran Kebiasanaan Merokok Anggota Keluarga Wilayah Kerja Puskesmas Ponre

Tabel 3 distribusi frekuensi Kebiasaan merokok anggota keluarga

\begin{tabular}{lll}
\hline $\begin{array}{l}\text { Kebiasaan } \\
\text { Merokok Anggota } \\
\text { Keluarga }\end{array}$ & F & $\begin{array}{l}\text { Presentase } \\
(\%)\end{array}$ \\
\hline Ada & 32 & 64,0 \\
\hline Tidak & 18 & 36,0 \\
\hline Jumlah & 50 & 100 \\
\hline
\end{tabular}

Table 3 menunjukkan bahwa dari 50 responden balita yang menderita ISPA dalam penelitian ini memiliki anggota keluarga yang tinggal bersama dengan kebiasaan merokok sebanyak 32 orang $(64,0 \%)$ dan 18 balita $(36,0 \%)$ memiliki anggota keluarga yang tinggal bersama tanpa kebiasaan merokok.

4. Gambaran Lokasi Kebiasaan Merokok Anggota Keluarga Wilayah Kerja Puskesmas Ponre

Tabel 4 distribusi frekuensi Lokasi Kebiasaan Merokok Anggota Keluarga

\begin{tabular}{|c|c|c|}
\hline Lokasi merokok & $\mathrm{F}$ & $\begin{array}{l}\text { Presentase } \\
(\%)\end{array}$ \\
\hline $\begin{array}{l}\text { Tanpa memperhatikan } \\
\text { lingkungan dengan balita } \\
\text { disekitar balita }\end{array}$ & 21 & 42,0 \\
\hline $\begin{array}{l}\text { Memperhatikan lingkungan } \\
\text { dengan tidak ada balita } \\
\text { disekitar perokok }\end{array}$ & 29 & 58,0 \\
\hline Jumlah & 50 & 100 \\
\hline
\end{tabular}

Sumber : Data Primer Tahun 2019

Tabel 4 menunjukkan bahwa dari 50 balita yang menderita ISPA memiliki anggota keluarga yang tinggal bersama dengan kebiasaan merokok, terdapat 21 anggota keluarga (42,0\%) yang memiliki kebiasaan merokok dengan tidak memperhatikan lingkungan dengan balita disekitar perokok dan 29 anggota keluarga $(58,0 \%)$ yang memiliki kebiasaan merokok dengan memperhatikan lingkungan dengan tidak ada balita disekitar perokok.

5. Gambaran Jumlah Anggota Keluarga Yang Memiliki Kebiasaan Merokok Wilayah Kerja Puskesmas Ponre

Tabel 5 Distribusi frekuensi Jumlah Anggota Keluarga Yang Memiliki KebiasaanMerokok

Jumlah anngota frekuensi Presentase
keluarga yang erokok

\begin{tabular}{lrl}
\hline Satu orang & 20 & 40,0 \\
\hline$>$ satu orang & 30 & 60,0 \\
\hline Jumlah & 50 & 100 \\
\hline \multicolumn{2}{l}{ Sumber : Data Primer (2019) }
\end{tabular}

Tabel 5 menunjukkan bahwa dari 50 anggota keluarga yang memiliki kebiasaan merokok tanpa memperhatikan lingkungan dengan balita disekitar perokok, terdapat 20 balita yang memiliki jumlah anggota keluarga $(40,0 \%)$ dengan kebiasaan merokok hanya satu orang, dan 30 balita yang 
memiliki jumlah anggota keluarga (60,0\%) dengan kebiasaan merokok sebanyak lebih dari satu orang.

6. Gambaran Banyaknya Rokok Yang Dihirup Setiap Hari Oleh Anggota Keluarga Wilayah Kerja Puskesmas Ponre

Tabel 6 Distribusi frekuensi Rokok Yang Dihirup Setiap Hari Oleh Anggota Keluarga

\begin{tabular}{ccc}
\hline $\begin{array}{l}\text { Jumlah Rokok } \\
\text { yang dihirup } \\
\text { setiap hari }\end{array}$ & $\begin{array}{l}\text { Frekuensi } \\
\text { (F) }\end{array}$ & $\begin{array}{l}\text { Presentase } \\
(\%)\end{array}$ \\
\hline Ringan & 12 & 24,0 \\
\hline Sedang & 24 & 48,0 \\
\hline Berat & 14 & 28,0 \\
\hline Jumlah & 50 & 100 \\
\hline
\end{tabular}

Sumber : Data Primer (2019)

Tabel 6. menunjukkan bahwa dari 50 anggota keluarga balita yang menderita ISPA dengan kebiasaan merokok masuk kategori penghirup rokok ringan sebanyak 12 responden $(24,0 \%)$, dan yang masuk kategori Sedang sebanyak 24 responden $(48,0 \%)$, kemudian yang masuk katergori Berat sebanyak 14 responden $(28,0 \%)$.

\section{PEMBAHASAN}

Adapun hasil dari penelitian yang dilaksanakan di wilayah kerja puskesmas ponre :

\section{1. karakteristik responder berdasarkan kebiasaan merokok anggota keluarga}

Dilihat Kebiasaan Merokok Anggota Keluarga hasil penelitian 45 responden (90\%) ini memiliki anggota keluarga yang tinggal bersama dengan kebiasaan merokok dan 5 balita $(10 \%)$ memiliki anggota keluarga yang tinggal bersama tanpa kebiasaan merokok.

Dari hasil penelitian ditemukan bahwa sebagian besar kepala keluarga merupakan perokok aktif, hal ini dapat mengganggu perokok pasif yaitu anggota keluarga yang tidak merokok namun terkena asap rokok, terutama anak-anak usia 1-5 tahun yang sering berada di dekat keluarga yang mempunyai kebiasaan merokok sehingga udara yang dihirupnya sudah terkontaminasi oleh asap rokok yang mangakibatkan radang tenggorokan, penyakit asma dan penyakit pernafasan lainnya. Untuk menghindari hal tersebut maka diperlukan kesadaran diri dan saling mengerti bagi keluarga yang mempunyai kebiasaan merokok untuk tidak merokok di dalam rumah dan bahkan dilingkungan rumah hal ini bertujuan untuk meminimalisir terjadinya penyakit pernapasan yang disebabkan oleh asap rokok.

Hasil penelitian ini sejalan dengan penelitian yang dilakukan oleh Nina Yulistyowati (2012) dengan judul "Gambaran kebiasaan merokokorang tua yang menderita ISPA pada balita di Puskesmas Siwala, Kabupaten Pekalongan" dengan hasil separuh orang tua balita yang menderita ISPA adalah perokok yaitu sebanyak $43(55 \%)$ responder dal sisanya yang tidak merokok yaitu 35 (45\%) responder.

Penelitian yang dilakukan oleh Goet et al $(2012)^{6}$ menyebutkan bahwa dari 234 balita yang menderita infeksi saluran pernafasan akut (ISPA), 183 balita $(78,20 \%)$ memiliki orang tua yang memiliki kebiasaan merokok dan 51 (21,8\%) memiliki orang tua tanpa kebiasaan merokok. Tingginya proporsi kebiasaan merokok orang tua pada balita yang menjadikan infeksi saluran pernafasan akut (ISPA) menjadi dasar bahwa kebiasaan merokok orang tua menjadi salah satu faktor yang bertanggung jawab terhadap kejadian infeksi saluran pernafasan akut (ISPA) pada balita yan tinggal bersama.

Adanya kebiasaan merokok anggota keluarga meningkatkan resiko balita yang tinggal bersama terpapar asap rokok yang mengandung banyak sekali bahan kimia berbahaya. Balita yang terpapar asap rokok juga akan meningkatkan resiko terhadap berbagai masalah kesehatan, termasuk diantaranya infeksi saluran pernafasan akur (ISPA).

\section{Disteribusi karakteristik responder berdasarkan lokasi kebiasaan merokok anggota keluarga.}

Hasil penelitian menunjukkan bahwa dari 50 balita yang menderita ISPA memiliki anggota keluarga yang tinggal bersama dengan kebiasaan merokok, terdapat 21 anggota keluarga balita $(42,0 \%)$ yang memiliki kebiasaan merokok dengan tidak memperhatikan lingkungan dengan balita disekitar perokok, dan 29 anggota keluarga $(58,0 \%)$ yang memiliki kebiasaan merokok dengan memperhatikan lingkungan dengan tidak ada balita disekitar perokok.

Penelitian yang sama yang dilakukan oleh Rohim (2014), kebiasaan anggota keluarga merokok di dalam rumah sebanyak 34 responden (62.9\%). Rokok merupakan salah satu zat adiktif, yang bila digunakan dapat mengakibatkan bahaya kesehatan bagi individu dan masyarakat. Berdasarkan Peraturan Pemerintah No.19 tahun 
2003, diketahui bahwa rokok adalah hasil olahan tembakau yang dibungkus, termasuk cerutu ataupun bentuk lainnya yang dihasilkan dari tanaman Nicotiana Tabacum, Nicotiana Rustica, dan spesies lainnya, atau sintetisnya yang mengandung nikotin dan tar dengan dan atau bahan tambahan. Perokok aktif adalah seseorang yang benar-benar memiliki kebiasaan merokok. Merokok sudah menjadi bagian hidupnya, sehingga rasanya tak enak bila sehari saja tidak merokok. Oleh karena itu, ia akan melakukan apa pun demi mendapatkan rokok, kemudian merokok.

\section{Distribusi karakteristik responder berdasarkan jumlah anggota keluarga yang memiliki kebiasaan merokok}

Hasil penelitian menunjukkan bahwa dari 50 anggota keluarga yang memiliki kebiasaan merokok tanpa memperhatikan lingkungan dengan balita disekitar perokok, terdapat 20 balita (40,0\%)yang memiliki jumlah anggota keluarga dengan kebiasaan merokok hanya satu orang dan 30 balita $(60,0 \%)$ yang memiliki jumlah anggota keluarga dengan kebiasaan merokok sebanyak lebih dari satu orang .

Penelitian yang dilakukan oleh trisnawati dan juwarni (2012) dalam penelitiannya membagi kebiasaan merokok keluarga menjadi 2 kategori, yaitu ringan dan sedang. Hasil penelitiannya menyebutkan bahwa dari 51 balita pada kelompok kasus (Menderia ISPA), 41 balita memiliki keluarga dengan kebiasaan merokok kategori berat. Sedangkan 51 balita kelompok kontrol, 39 balita memiliki keluarga dengan kebiasaan merokok kategori ringan. Dilihat dari hasil tersebut dapat yang semakin berat maka semakin besar pula potensi balita untuk menderita infeksi saluran pernafasan akut (ISPA).

\section{Distribusi karakteristik responder berdasarkan banyaknya rokok yag dihirup setiap hari oleh anggota keluarga.}

Hasil ini menunjukkan bahwa dari 50 anggota keluarga dengan kebiasaan merokok ringan (1-10 btg/hari) sebanyak 12 responden(24,0\%), 24 balita yang memiliki jumlah anggota keluarga dengan merokok sedang (11-20 btg/hari) sebanyak 24 responden $(48,0 \%)$ dan 14 responden $(28 \%)$ yang memiliki jumlah anggota keluarga dengan kebiasaan merokok berat (20 btg/hari).

Penelitian yang dilakukan Zuhriyah (2015) Menyebutkan bahwa dari 43 balita ISPA yang memiliki anggota keluarga dengan kebiasaan merokok tanpa memperhatikan lingkungan balita di sekitar perokok, terdapat 2 kelompok kebiasaan merokok anggota keluarga dengan presentase yang sama, yaitu15 balita $(34,88 \%)$ memiliki anggota keluarga dengan kebiasaan merokok berat, 15 balita $(34,88 \%)$ memiliki anggota keluarga yang memiliki kebiasaan merokok sedang. Peningkatan polusi asap rokok dalam rumah dapat menyebabkan meningkatkan paparan asap rokok terhadap balita. Tingginya paparan asap rokok itu pula yang dapat meningkatkan resiko balita yang tinggi dalam satu rumah untuk menderita infeksi saluran pernafasan akut (ISPA).

\section{Distribusi karakteristik responder berdasarkan Pendidikan dari anggota keluarga.}

Dari data responden pada penelitian ini, terdapat 4 responden $(8,0 \%)$ yang lulusan perguruan tinggi (S1 dan D3), dan terdapat 17 responden $(34,0 \%)$ yang berpendidikan menengah (SMP dan SMA). Selebihnya berpendidikan dasar (SD) dan tidak sekolah sebanyak 29 responden (85,0\%).Tingkat pendidikan seseorang akan menentukan pola pikir dan wawasan selain itu pendidikan juga merupakan bagian dari pengalaman kerja. Semakin tinggi pendidikan seseorang maka diharapkan pengetahuan dan keterampilan akan semakin meningkat. Lewat pendidikan manusi dianggap akan memperoleh pengetahuan dan semakin tinggi pendidika akan semakin berkualitas.

\section{KESIMPULAN}

Berdasarkan hasil penelitian dan pembahasan mengenai Gambaran Kebiasaan Merokok Anggota Keluarga Dengan Kejadian Infeksi Saluran Pernafasan Akut (ISPA) Pada Balita Di Wilayah Kerja Puskesmas Ponre sebagai berikut:

1. Sebagian besar (64\%) anggota keluarga balita penderita ISPA adalah perokok.

2. Anggota keluarga balita penderita ISPA berada dalam kategori perokok sedang $(48 \%)$ dan berat $(28 \%)$.

3. Sebagian besar $(58 \%)$ balita penderita ISPA tinggal bersama anggota keluarga yang memiliki kebiasaan merokok dengan tidak memperhatikan lingkungan .

4. Sebagian besar jumlah rokok yang di hirup oleh anggota keluarga kategori sedang sebanyak 24 responden (48\%). 


\section{DAFTAR PUSTAKA}

1. Rahmayatul, F. (2013). Hubungan Lingkungan Dalam Rumah Tangga Terhadap ISPA Pada Balita. Jakarta.

2. World Health Organization WHO (2015) : global health observatory causes of chily mortalithyhhtp://www.who.int.gho.child health/mortality/mortality under five/en/ diakses 18 november 2018.

3. Depertemen Kesehatan Republik Indonesia (2014), Riset Kesehatan Dasar (Riskesdas). Jakarta : Depertemen Kesehatan
4. Umami, R.M. (2014). Perencangan Dan Pembuatan Alat Pengendali Asap Rokok Berbasis Mikrokonteler. Jakarta : Medika Cipta.

5. Notoatmojo, S, 2013. Metodologi Penelitian Kesehatan, Edisi Revisi, Rineka Cipta, Jakarta.

6. Goel, Kapil., Et Al. (2012) A Cross Sectional Studyon Prevalence If Acute Respiration Infections (ARI) In Under-Five Childer Of Meerut District, India.J Community Medical \& Health Educatin, 2(9) :1-4. 